\title{
RANCANGAN TAHAPAN (PUSHBACK) PENAMBANGAN ENDAPAN BIJIH NIKEL PADA PT. HENGJAYA MINERALINDO (HM) KECAMATAN BUNGKU PESISIR KABUPATEN MOROWALI PROVINSI SULAWESI TENGAH
}

\author{
Sahrul $^{1}$, Musnajam $^{1}$, Asnun $^{2}$ \\ Teknik Pertambangan Universitas Sembilanbelas November Kolaka \\ Sulawesi Tenggara \\ Email Koresponding : 17sahrulpoalahi@gmail.com, \\ Asnunmuhammad93@gmail.com
}

\begin{abstract}
ABSTRAK
PT. Hengjaya Mineralindo $(H M)$ merupakan salah satu perusahaan swasta di bidang pertambangan yang mengelola dan mengolah endapan bijih nikel dengan Ijin Usaha Pertambangan (IUP) Eksploitasi Nomor 540.3/SK.001/DESDM/VI/2011 seluas 6.249 Ha yang berlokasi di Kecamatan Bungku Pesisir Kabupaten Morowali Provinsi Sulawesi Tengah. Sebagian wilayah Ijin Usaha Pertambangan Eksploitasi tersebut telah di tambang pada tahun sebelumnya dan selanjutnya akan dilakukan pembukaan pit baru di Blok B1 pit APL berdasarkan kegiatan Eksplorasi yang memenuhi kriteria cadangan bijih nikel berkadar tinggi. Berdasarkan alasan tersebut, diperlukan kegiatan pemodelan, perhitungan cadangan serta rancangan tahap-tahap (pushback) penambangan untuk memenuhi kebutuhan penjadwalan rancangan penambangan dan perencanaan tambang berikutnya. Studi ini dilakukan untuk menentukan rancangan tahapan (pushback) penambangan yang mempertimbangkan faktor keamanan dan perolehan tambang (mining recovery) menggunakan Sofware Gemcom Surfac 6.3. Dari pemodelan endapan bijih nikel ini diharapkan akan diketahui tonase cadangan bijih nikel dan overburden yang akan dikupas sekaligus bentuk desain pit penambangan yang memenuhi kriteria keamaman. Berdasarkan hasil permodelan yang dilakukan di Blok B1 pit APL, diketahuitotal tonase cadangan endapan bijih nikel yang ditambang sebesar 61.379 ton sedangkan tonase Overburden sebesar 170.139 ton (stripping raio 1:2,8). Adapun desain kemiringan lereng tunggal (single ultimate pit slope) maksimal yang diperoleh adalah $60^{\circ}$, dengan tinggi dan lebar bench masing-masing 4 meter dan 1.33 meter serta lebar jenjang kerja 2,66 meter.
\end{abstract}

Kata Kunci : Cadangan, Perancangan dan Geometri Penambangan. 


\section{PENDAHULUAN}

\section{A. Lokasi Penelitian}

PT. Hengjaya Mineralindo merupakan salah satu perusahaan swasta yang bergerak di bidang pertambangan Nikel dengan wilayah konsesi Ijin Usaha Pertambangan Operasi Produksi Nomor 540.3/SK.001/DESDM/VI/2011 dengan target produksi sebesar 30.000 WMT/bulan pada lahan seluas 1.000 Ha. Lokasi Ijin Usaha Pertambangan PT. Hengjaya Mineralindo berada di Desa Tangofa dan Pungkeu, Kecamatan Bungku Pesisir, dan Desa Bete-Bete, Kecamatan Bahodopi, Kabupaten Morowali, Propinsi Sulawesi Tengah (lihat gambar 1). lokasi konsesi dapat di tempuh dari kota Jakarta, perjalanan diawali dengan penerbangan dari Jakarta menuju kota Kendari, yang diteruskan dengan menempuh perjalanan jalan darat selama kurang lebih 8 jam, hingga ke Desa Tangofa.

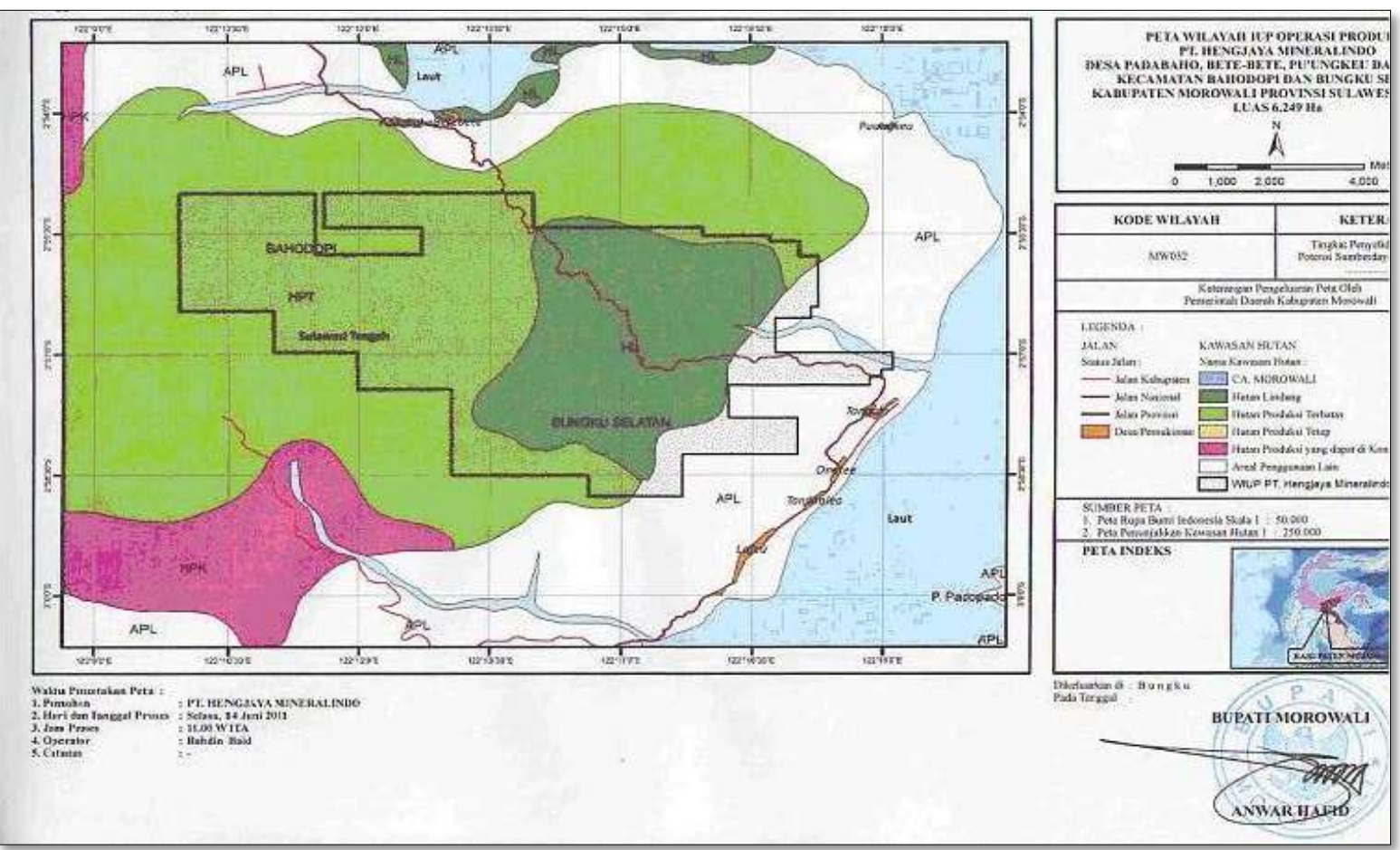

Gambar 1 : Peta Koodinat Ijin Usaha Produksi (IUP) PT. Hengjaya Mineralindo

(Sumber : PT. Hengjaya Mineralindo)

\section{B. Geologi Ragional Daerah Penelitian}

Batuan magmatik potassic calc-alkaline berusia akhir Miosen di Sulawesi Tengah terdapat di bagian kiri bentangan Zona sesar Palu- Koro, dimana batuan Granit di wilayah tersebut berkorelasi dengan subduksi microcontinent Banggai-Sula dengan Pulau Sulawesi pada pertengahan Miosen. Berdasarkan aspek petrografi, batuan granit berumur Neogen 
tersebut dapat diklasifikasikan menjadi tiga kelompok dari yang paling tua sampai dengan yang termuda untuk melihat karakteristik perubahannya di masa mendatang. Pertama adalah bantalan Granit yang kasar (Granitoid-C) yang terdistribusi di bagian utara dan selatan wilayah Palu-Koro yang berumur 8,39-3,71 Ma, dimana dua karakteristik petrografi tersebut dapat dibedakan menjadi dua, yaitu Biotit yang mengandung Granit dan Hornblende sebagai mineral mafik (4,15-3,71 Ma dan 7,05-6,43 Ma) dan Biotit yang mengandung granit sebagai mineral mafik utama (8,39-7,11Ma). Kelompok kedua adalah batuan Granit medium mylonitic-gneissic (Granitoid-B) yang relatif terdapat di daerah pusat (sekitar Palu-Kulawi) berupa medium grained granitoids yang kadang- kadang mengandung xenoliths.

Batuan Granit ini juga dapat dibagi lagi menjadi hornblende-biotit yang terdistribusi di bagian selatan (Saluwa-Karangana) sekitar 5,46-4,05 Ma dan granit bantalan Biotit yang berumur 3,78-3,21 Ma di sekitar Kulawi. Kelompok ketiga adalah Fine andbiotitepoorgranitoid (Granitoid-A) kelompok batuan termuda yang tersebar di daerah Palu-Koro sekitar 3,07-1,76 Ma, yang nampak sebagai dyke kecil hasil potongan dari Granit lain. Batuan tersebut berwarna putih bersih mengandung sejumlah biotitessebagai mineral mafik tunggal, kebanyakan batuan tersebut.

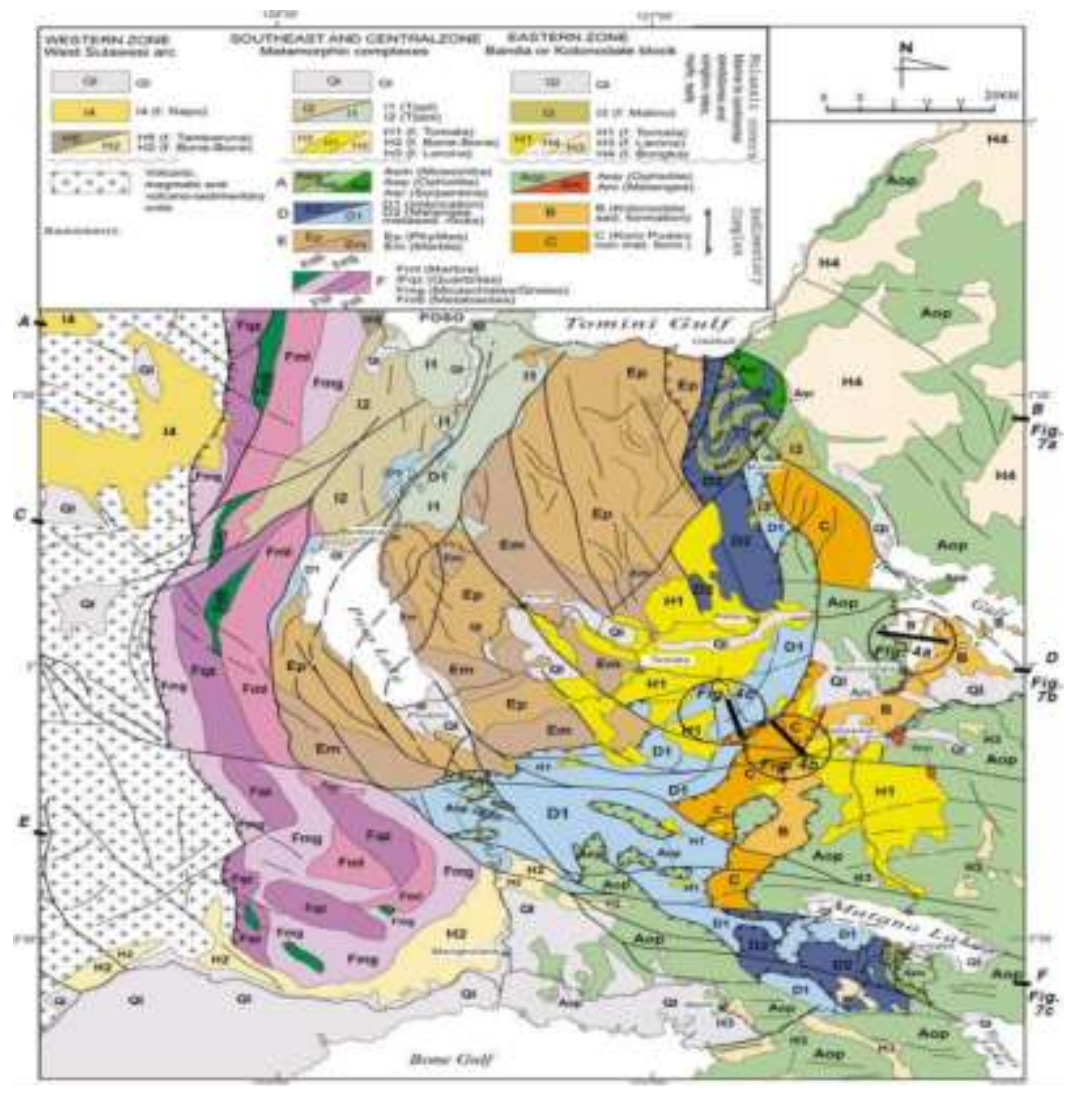




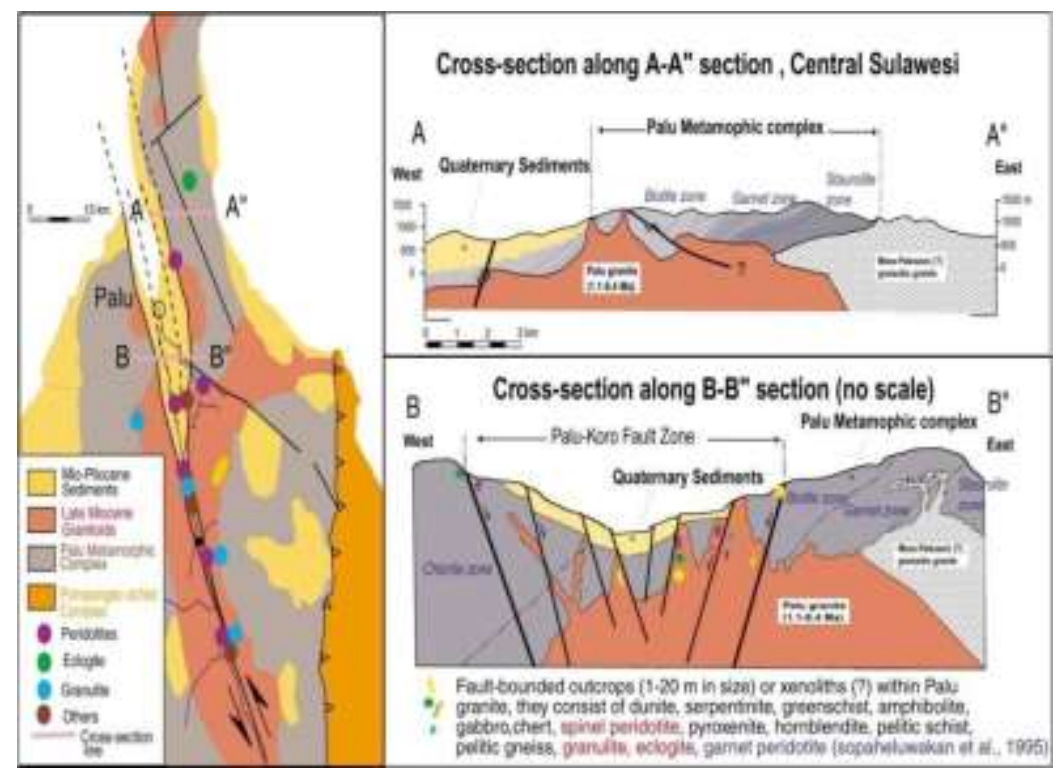

Gambar 3 : Peta Geologi Sulawesi Tengah (Villeneuve dkk.,2002)

\section{Zona Lateritisasi Pada Daerah Penelitian}

Pada Blok-blok tersebut sudah dilakukan pemboran detail dengan grid $100 \mathrm{~m}-25 \mathrm{~m}$, terdapat singkapan saprolit yang cukup meyakinkan, adanya indikasi mineral-mineral garnierite yang berkembang ke arah utara dan selebihnya perkembangan kearah timur, terjadi perubahan kualitas menjadi batuan ultramafik (serpentinit) yang masih fresh. Berdasarkan hasil penggalian tespit pada Block B, maka rata-rata kedalaman laterit yang diperoleh antara 3 - 6 m. Lithologi yang didapatkan masih Ferruginous saprolite. Hal ini disebabkan kondisi batuan peridotit yang terserpentinisasi memiliki tingkat serpentinisasi yang berbeda-beda sehingga menghasilkan profil Laterite yang bervariasi.

Pada umumnya daerah penelitian merupakan Silicates Laterite dengan ditandai banyaknya Pisolit dan Hematite dipermukaan. Keadaan permukaan tanah seperti ini dapat menghasilkan tespit yang cukup dalam. Keberadaan butiran Pisolite yang melimpah di permukaan merupakan salah satu ciri keberadaan Silicates Laterite pada suatu daerah. Berdasarkan kenampakan visual tespit menghasilkan profile Limonit - Ferruginous Saprolite yang cukup bagus, dengan ditandai adanya Manganese Oxide dan Chromite streaks. Ferruginous Saprolite dapat terus berkembang hingga kedalaman $10-11 \mathrm{~m}$ dangkal lateritnya, namun kaya akan mineral Garnierite yang terdapat pada rekahan batuannya, memungkinkan kandungan unsur nikel yang sangat tinggi, dan dapat dimungkinkan bisa menjadi sebuah Injector pada saat pengapalan dangan hasil penambangan yang memiliki kandungan kadar Nikel yang rendah. 


\section{HASIL PENELITIAN DAN PEMBAHASAN}

\section{A. Pemodelan Endapan Bijih Nikel}

Data-data yang diperlukan dalam proses pemodelan geologi ini adalah data rekapitulasi lubang bor, berupa nama titik bor, elevasi titik bor, koordinat titik bor, kedalaman lubang bor. Pemodelan geologi bertujuan untuk mendapatkan data dalam penaksiran cadangan endapan bijih nikel, sehingga memenuhi syarat dilakukan penambangan. Pemodelan geologi ini juga bertujuan untuk mengetahui bentuk penyebaran endapan bijih nikel, baik geometri secara umum, letak/posisi, kedalaman, kemiringan, serta penyebaran dari tanah penutup. Proses pemodelan geologi ini didapatkan dari data lubang bor yang diinput kedalam Software Arcgis 9.3. Pada blok B1 pit APL seluas 3 ha ada 60 lubang bor yang digunakan untuk menganalisa bentuk penyebaran endapan bijih nikel tersebut. Dengan kedalaman lubang bor yang berbeda-beda yaitu dari kedalaman 5 meter hingga kedalaman 53 meter. Peta sebaran lubang bor dapat dilihat pada gambar dibawah ini.
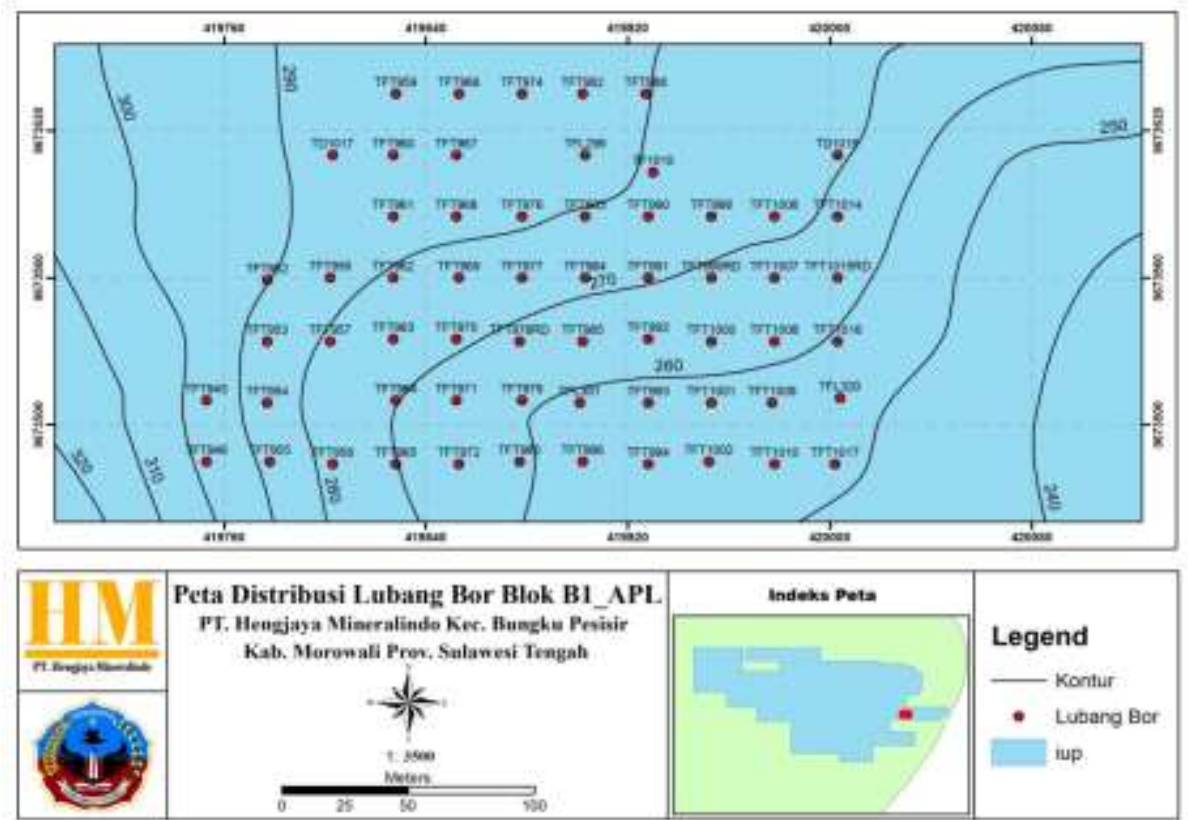

Gambar 4. Sebaran Titik Lubang Bor (Damri Lolongan, 2015) 


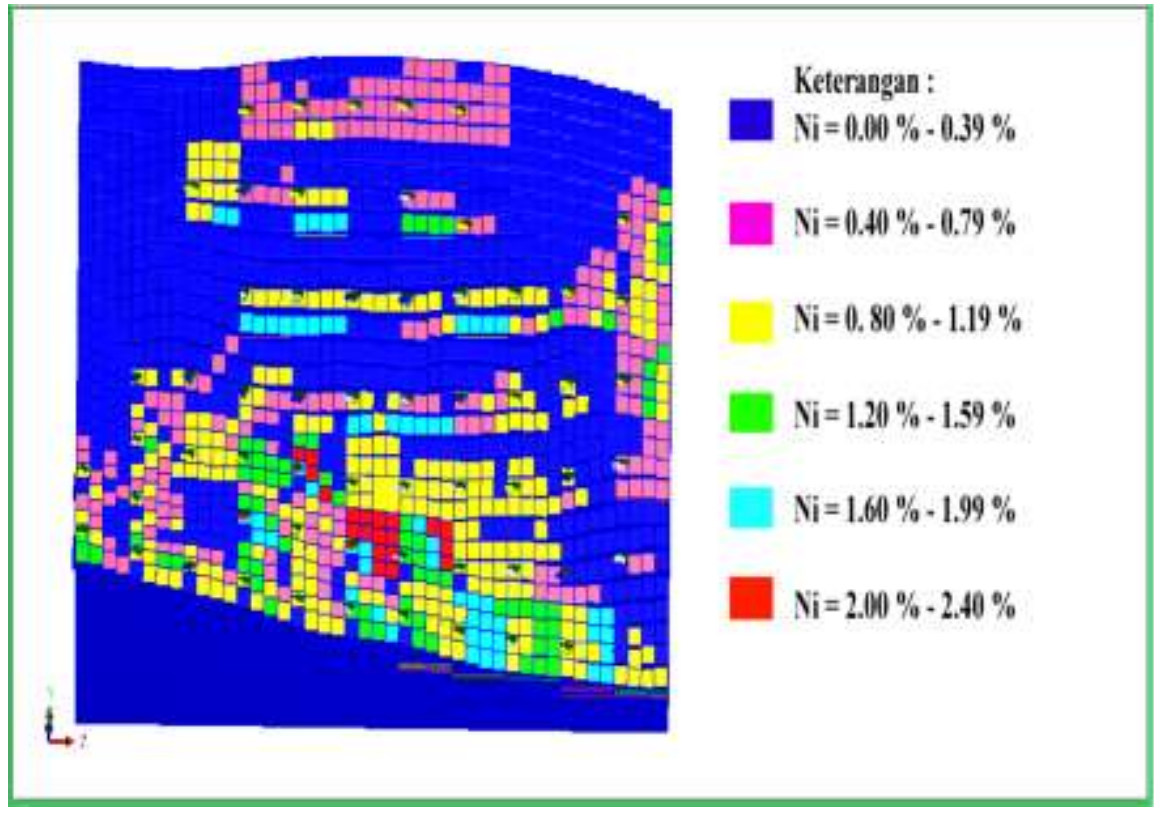

Gambar 5. Bentuk Penyebaran Sumberdaya Endapan Bijih Nikel (Asnun, 2016)

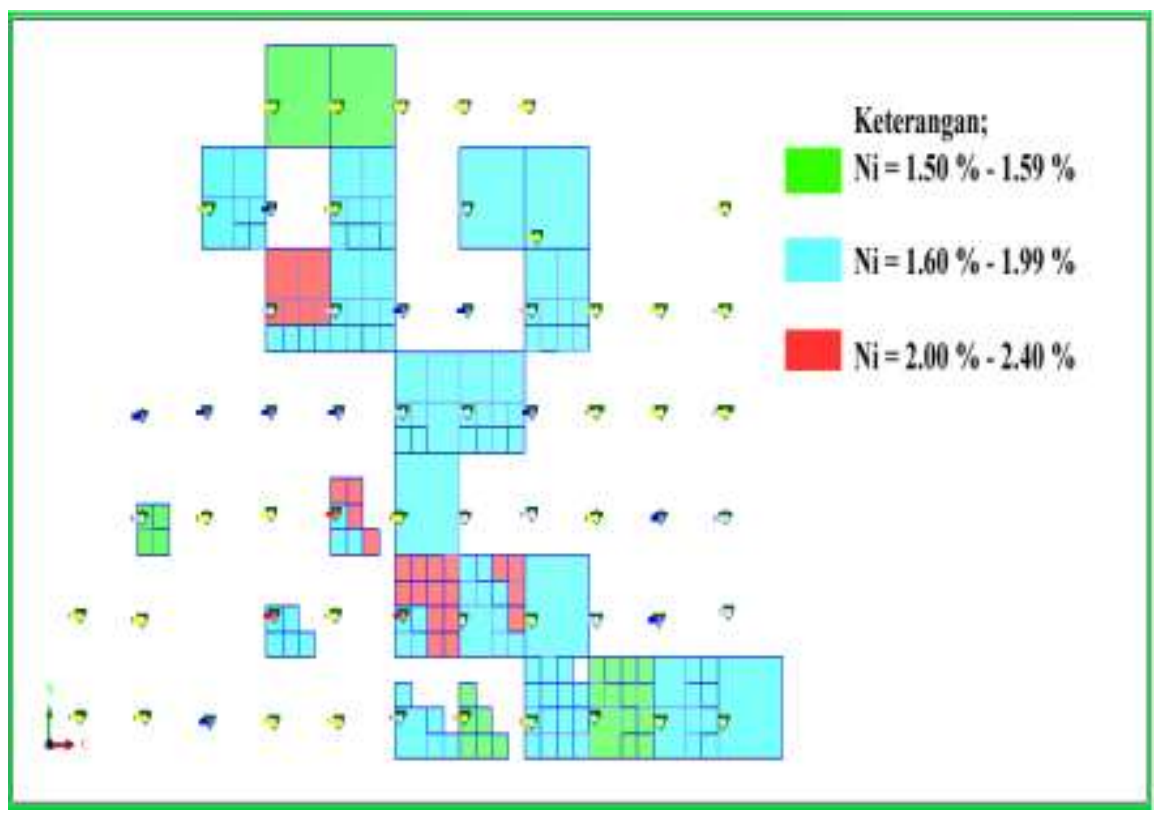

Gambar 6. Bentuk Penyebaran Cadangan Endapan Bijih Nikel (Asnun, 2016)

Data pemboran yang dibutuhkan untuk pemodelan diambil menjadi dua yaitu data pemboran survey meliputi : nama titik bor, elevasi titik bor, koordinat titik bor, kedalaman lubang bor. Data survey ini berguna untuk memberikan informasi tentang lokasi titik-titik bor, sehingga dapat digambarkan pada lokasi penelitian. Data pemboran geologi meliputi : nama titik bor, batas kedalaman lapisan atas dan batas kedalaman lapisan bawah, dan kode lithologi. Kemudian dari data bor tersebut dapat dihasilkan peta penyebaran endapan bijih nikel, sehingga kita dapat mengetahui letak dan bentuk sebaran endapan bijih nikel diblok 
APL. Berdasarkan hasil pemodelan diatas diperoleh bahwa jumlah sumberdaya endapan bijih nikel yaitu 2.149.175 WMT, sedangkan jumlah cadangan endapan bijih Nikel yang dimiliki sebesar 127.524.

\section{B. Sistem Penambangan}

Sistem penambangan yang akan diterapkan oleh PT.Hengjaya Mineralindo $(H M)$ adalah sistem tambang terbuka open pit mining. Penentuan sistem penambangan yang digunakan sangat dipengaruhi oleh beberapa hal diantaranya adalah :

a. Letak kedalaman endapan, apakah dekat dengan permukaan bumi atau jauh dari permukaan bumi.

b. Pertimbangan ekonomis yang tujuannya untuk memperoleh keuntungan yang maksimal dengan "Mining Recovery" yang maksimal dan relatif aman.

c. Pertimbangan teknis.

d. Pertimbangan teknologi yang akan digunakan.

Secara garis besar aktivitas penambangannya dimulai dari pembersihan lahan tambang (land clearing), pengupasan lapisan penuutup (striping), penggalian (loosening), pemuatan dan pengangkutan, pencampuran (Blending), Penimbunan pada stockyard dan penjualan.

\section{Rancangan Batas Akhir Penambangan (Ultimate Pit Limit) Pit APL Block B1}

Penentuan rancangan batas akhir kegiatan penambangan (Ultimate Pit Limit) mempertimbangkan perolehan maksimal jumlah cadangan yang dapat ditambang (tonase dan $C O G)$ dari total endapan bijih yang tersedia. Parameter-parameter yang dipertimbangkan dalam menentukan rancangan batas akhir penambangan adalah Cut Off Grade (COG) atau nilai kadar batas ekonomis tambang yaitu $\mathrm{Ni} 1.5 \%$ dan kadar batas ekonomis rata-rata yaitu Ni $1.8 \%$, jumlah Stripping Ratio (SR) yang diperbolehkan oleh perusahaan yaitu SR $\leq 3: 1$, rekomendasi geoteknik untuk kemiringan akhir jenjang yaitu $60^{\circ}$ dan batas izin usaha pertambangan (IUP) eksploitasi, perkampungan, hutan lindung, jalan, dan sungai.

Untuk memperkirakan volume overburden dan bijih nikel yang dirancang, digunakan metode perhitungan dengan bantuan software gemcom surfac 9.3. Perhitungan ini menggunakan block model 3 dimensi untuk menentukan volume berdasarkan batas - batas pit yang dibuat. 
Dalam perhitungan volume pit yang dilakukan ukuran block model yang digunakan yaitu untuk Parent cell atau blok yang paling utama dan paling besar dibentuk yaitu $25 \mathrm{~m} \mathrm{x}$ $25 \mathrm{~m}$ x $2 \mathrm{~m}$ (x y z) sedangkan sub cell atau blok yang dibuat lebih kecil yaitu 12,5 m x 12,5 m x $1 \mathrm{~m}$ dan $6,25 \mathrm{~m} \times 6,25 \mathrm{~m} \times 0.5 \mathrm{~m}$ serta batas dari pit yang digunakan sebagai batas perhitungan yaitu topografi sebagai batas atas penambangan (top surface) sedangkan yang menjadi batas bawah penambangannya (bottom surface) yaitu rancangan batas akhir penambangan (ultimate pit limit) maka didapatkan volume overburden yang dihasilkan dari Pit tersebut sebanyak 178.601 ton sedangkan untuk bijih nikel sebanyak 61.379 ton. Ukuran block model dan batas- batas dari pit dapat dilihat pada gambar 7 dibawah ini:

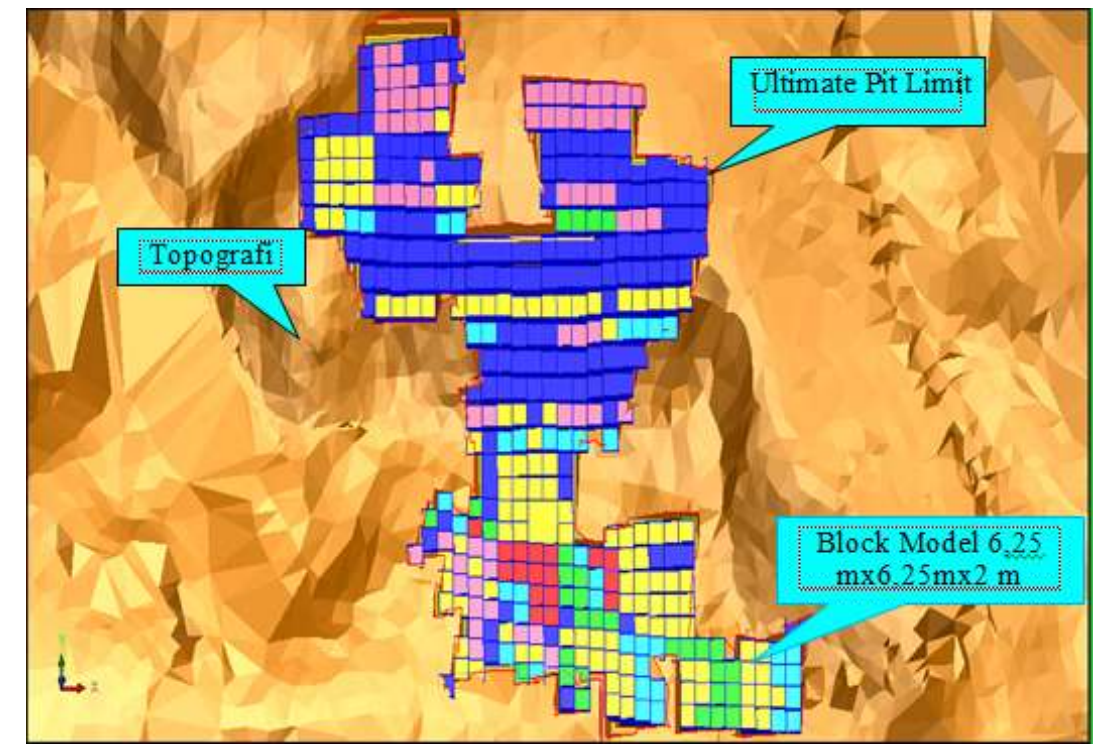

Gambar 7. Ukuran Block Model dan Batas -Batas Pit (Asnun, 2016)

Penentuan rancangan batas akhir penambangan yang tampilkan dalam penelitian ini merupakan rancangan batas akhir penambangan selama 1 minggu menggunakan software Gemcom Surfac 9.3. Tahap penentuan rancangan batas akhir penambangan yang dilakukan pada Pit APL Blok B1 direpresentasikan melalui sebuah garis potong A ke A' dengan mempertimbangkan perubahan topografi signifikan yang terjadi seiring proses pengupasan setiap harinya. Tahapan pengupasan atau penggalian OB dan bijih nikel dalam tujuh hari diuraikan lebih lanjut sebagai berikut :

\section{Tahapan Penambangan bijih nikel hari pertama}

Tahapan Penambangan bijih nikel pada hari pertama dilakukan pada elevasi 282 272 mdpl dengan luas bukaan 0,49 ha. Adapun jumlah endapan bijih nikel yang diperoleh 
sebesar 2.503 ton dan Overburden sebesar 30.571 ton, dengan perbandingan stripping ratio adalah $12: 1$.

\section{Tahapan Penambangan bijih nikel hari kedua}

Tahapan Penambangan bijih nikel pada hari kedua dilakukan dari elevasi 272 sampai elevasi 266 dengan luas bukaan 0,25 ha. Adapun jumlah endapan bijih nikel yang diperoleh sebesar 10.085 ton dan Overburden sebesar 22.989 ton, dengan perbandingan stripping ratio adalah $2: 1$

\section{Tahapan Penambangan bijih nikel hari ketiga}

Tahapan Penambangan bijih nikel pada hari ketiga dilakukan dari sebahagian elevasi 266 sampai pada sebahagian elevasi 254 dengan luas bukaan 0,35 ha. Adapun jumlah endapan bijih nikel yang diperoleh sebesar 5.423 ton dan untuk overburden sebesar 27.651 ton, dengan perbandingan stripping ratio adalah $5: 1$.

\section{Tahapan Penambangan bijih nikel hari keempat}

Tahapan Penambangan bijih nikel pada hari keempat dilakukan dari sebahagian elevasi 254 sampai pada elevasi 242 dengan luas bukaan 0,39 ha. Adapun jumlah endapan bijih nikel yang diperoleh sebesar 3.041 ton dan untuk overburden sebesar 30.033 ton, dengan perbandingan stripping ratio adalah 9,87: 1 .

\section{Tahapan Penambangan bijih nikel hari kelima}

Tahapan Penambangan bijih nikel pada hari kelima dilakukan dari sebahagian elevasi 242 sampai pada elevasi 236 dengan luas bukaan 0,32 ha. Adapun jumlah endapan bijih nikel yang diperoleh sebesar 14.084 ton dan untuk overburden sebesar 18.990 ton, dengan perbandingan stripping ratio adalah 1,3: 1 .

\section{Tahapan Penambangan bijih nikel hari keenam}

Tahapan Penambangan bijih nikel pada hari keenam dilakukan dari sebahagian elevasi 236 sampai pada elevasi 232 dengan luas bukaan 0,62 ha. Adapun jumlah endapan bijih nikel yang diperoleh sebesar 12.249 ton dan untuk overburden sebesar 20.825 ton, dengan perbandingan stripping ratio adalah $1.7: 1$. 


\section{Tahapan Penambangan bijih nikel hari ketujuh}

Tahapan Penambangan bijih nikel pada hari ketujuh dilakukan dari sebahagian elevasi 232 sampai pada elevasi 226 dengan luas bukaan 0,39 ha. Adapun jumlah endapan bijih nikel yang diperoleh sebesar 13.994 ton dan untuk overburden sebesar 19.080 ton, dengan perbandingan stripping ratio adalah $3,2: 1$.

Tahap rancangan penentuan batas akhir penambangan selama satu minggu (tujuh hari) secara keseluruhan dapat dilihat pada gambar 9 dengan estimasi jumlah pengupasan overburden dan endapan nikel (striping ratio) yang ditampilkan dalam tabel 1.

Tabel 1. Estimasi jumlah pengupasan overburden dan endapan nikel (striping ratio)

\begin{tabular}{ccccc}
\hline Tahap & Elevasi & Overburden (ton) & Bijih Nikel (ton) & Striping Ratio (SR) \\
\hline Hari 1 & $282-272$ & 30.571 & 2.503 & $12: 1$ \\
\hline Hari 2 & $272-266$ & 22.989 & 10.085 & $2: 1$ \\
\hline Hari 3 & $266-254$ & 27.651 & 5.423 & $5: 1$ \\
\hline Hari 4 & $254-242$ & 30.033 & 3.041 & $10: 1$ \\
\hline Hari 5 & $242-236$ & 18.990 & 14.084 & $1,7: 1$ \\
\hline Hari 6 & $236-232$ & 20.825 & 12.249 & $3,2: 1$ \\
\hline Hari 7 & $232-226$ & 19.080 & 13.994 & \\
\hline
\end{tabular}



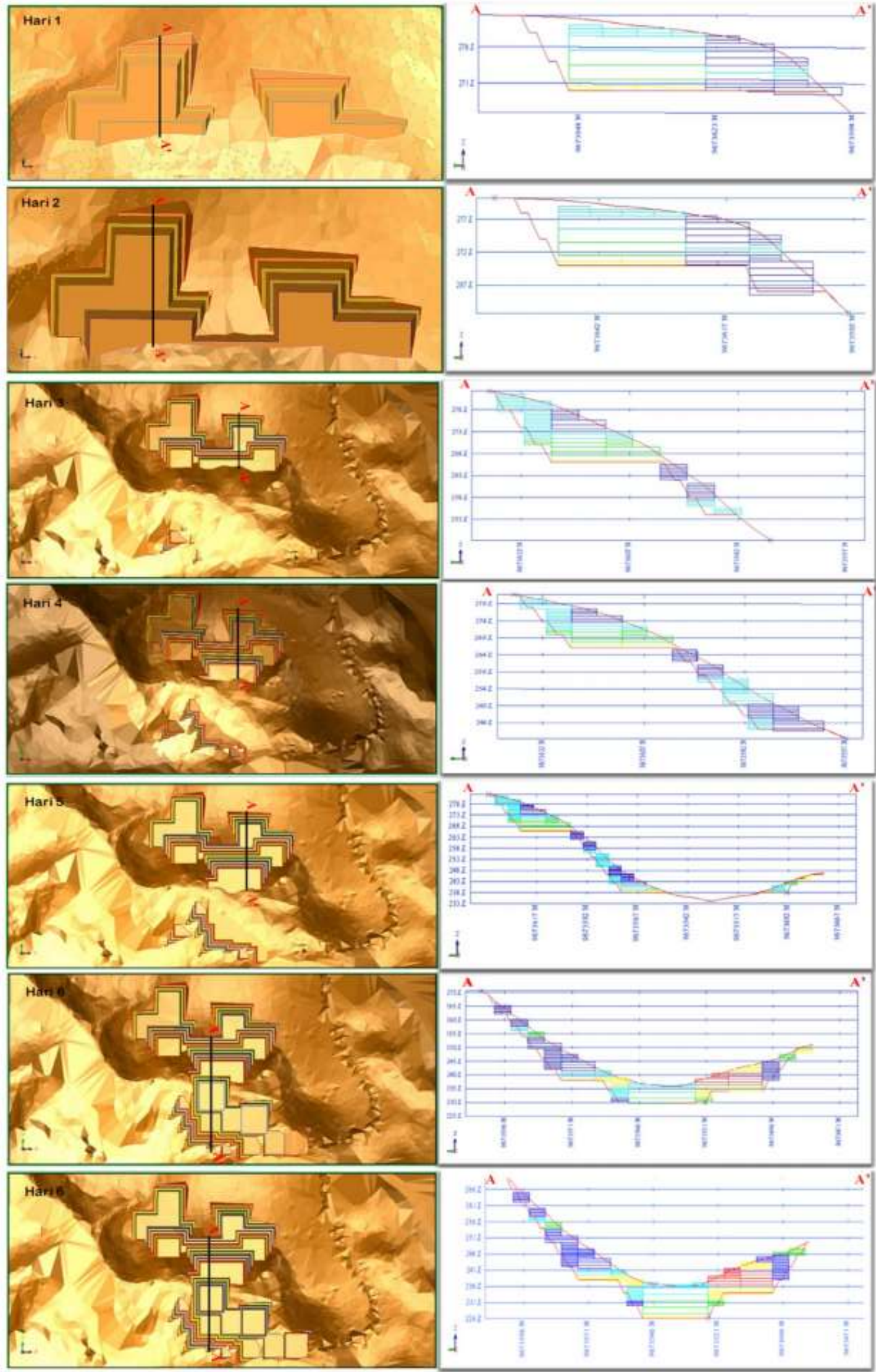

Gambar 9. Tahap rancangan penentuan batas akhir penambangan (Asnun, 2016). Tampak atas (kiri) dan penampang vertikal (kanan) 


\section{KESIMPULAN}

Berdasarkan hasil penelitian yang telah dilakukan, perancangan tahapan (pushback) penambangan sangat bermanfaat dalam mengontrol target produksi penambangan yang ingin dicapai. Perancangan tahapan (pushback) penambangan dengan menggunakan bantuan program permodelan komputer sangat membantu dalam mengontrol kemajuan penambangan secara efektif dan efisien.

Dari perancangan tahapan (pushback) penambangan mingguan selama tujuh hari menggunakan bantuan program permodelan surfac gemcom 9.3 di Pit 1 Blok APL PT. Hengjaya Mineralindo menunjukkan bahwa secara keseluruhan perbandingan antara total tonase overburden yang harus dikupas sebesar 170.139 ton sedanglan total cadangan bijih nikel yang dapat ditambang sebesar 61.379 ton (striping ratio $1: 2,8$ ). Adapun desain kemiringan lereng tunggal (single ultimate pit slope) maksimal yang diperoleh adalah $60^{\circ}$, dengan tinggi dan lebar bench masing-masing 4 meter dan 1.33 meter serta lebar jenjang kerja 2,66 meter.

\section{UCAPAN TERIMA KASIH}

Ucapan terima kasih yang sebesar besarnya ditujukan kepada PT. Hengjaya Mineralindo dan Program Studi Teknik Pertambangan Universitas Sembilanbelas November Kolaka atas ijin menggunakan lokasi penambangan dan peralatan laboratorium yang diberikan sehingga penelitian ini dapat terselesaikan dengan baik.

\section{DAFTAR PUSTAKA}

Agus H.,2005.,Metode Perhitungan Cadangan. ITB. Bandung.

Badan Standardisasi Nasional, 1998, Standar Klasifikasi Sumber Daya Mineral dan Cadangan, SNI No. 13-4726-1998.

Djadjulie A.,.2014.,Perencanaan Tambang. Materi Kuliah Prodi Keinspekturan, STEM Akamigas.

Hamilton.,1979.,Struktur Geologi Sulawesi, Perpustakaan Sains Kebumian ITB Bandung, 2012

Prodjosumarto P.,1995.,Pemindahan Tanah Mekanis. Bandung: ITB.

Simandjuntak.,1983.,Lithology dan Stratigrafi Wilayah Sulawesi.

Sompotan,A.,2012.,Struktur Geologi Sulawesi. Bandung: ITB.

Waterman S.,2010.,Perencanaan Tambang. Jogjakarta:Anugrah Print. 
A.R. Ardhyanto Tino.,1995.,Open Pit Optimization:A Comparative Study on the Application of Moving Cone and Lerchs - Grossmann Methods, Thesis Master of Engineering, Golder Colorado.

Villeneuve $d k k ., 2002$, Struktur Geologi Sulawesi,Perpustakaan Sains Kebumian Institut Teknologi Bandung, 2012.

Waterman S.,2010. Perencanaan Tambang. Yogyakarta: UPN Yogyakarta.

Hustrulid W. and Kuchta M.,1995. Open Pit Mine Planning \& Design. Vol I, A.A. 